Contributions:

A Study design/planning

B Data collection/entry

C Data analysis/statistics

D Data interpretation

E Preparation of manuscript

F Literature analysis/search

$\mathrm{G}$ Funds collection

\title{
INVESTIGATING THE SATISFACTION OF CLINICIANS AND CLIENTS IN A TELEAUDIOLOGY TRIAL
}

\section{Michael Thrum ${ }^{1 A C D E}$, Carlie Driscoll ${ }^{1 A D E}$, Tegan Keogh ${ }^{2 A B C D E}$}

${ }^{1}$ University of Queensland, School of Health \& Rehabilitation Sciences, Brisbane, Australia.

${ }^{2}$ HearCheck, Maroochydore, Australia.

Corresponding author: Assoc/Prof Carlie Driscoll, School of Health and Rehabilitation Sciences, The University of Queensland, St Lucia, QLD 4072, Australia. Tel: +61 73365 3095, E-mail: carlie.driscoll@uq.edu.au

Sources of support: This project was partially funded by a Knowledge Transfer Partnership Program Project Grant from the Queensland Government.

\begin{abstract}
Background: Thus far, the uptake of telehealth in Australia has been puzzlingly small in scale and sporadic in nature. This is particularly true of audiology. The current study aimed to investigate the satisfaction of clinicians and clients with audiology appointments in a trial of the telehealth mode.

Material and methods: A mixed-methods study design was utilised involving surveys with all appointment participants and semi-structured post-appointment interviews with clients. Appointments were conducted with 11 individual clients; of these, 7 interviews were conducted. One audiologist and one allied health assistant were used for all appointments.

Results: High satisfaction ratings overall were given by both clients ( $87.3 \%$ excellent) and the allied health assistant ( $74.4 \%$ excellent), whereas the audiologist consistently provided slightly lower levels of satisfaction $(72.7 \%$ good). It was also found that the audiologist believed that teleaudiology increased the quality of care offered.

Conclusion: By examining the perspectives of all key stakeholders, this study identifies a number of novel positive and negative aspects of a teleaudiology practice and offers suggestions for future implementation of such a program.
\end{abstract}

Key words: client $\bullet$ clinician $\bullet$ satisfaction $\bullet$ teleaudiology $\bullet$ telehealth

\section{SATISFACCIÓN DE CLÍNICOS Y PACIENTES EN UN CONSULTA DE TELEAUDIOLOGÍA}

\section{Resumen}

Antecedentes: hasta el momento, la aceptación de la telesalud en Australia ha sido incomprensiblemente pequeña y de carácter esporádico. Esto es particularmente cierto en la audiología. El presente estudio tiene como objetivo investigar la satisfacción de los clínicos y pacientes en las consultas de audiología en un ensayo del modelo de telesalud.

Material y métodos: se realizó un estudio de diseño mixto que incluía encuestas a todos los participantes de las consultas y entrevistas semiestructuradas posteriores a la consulta con los pacientes. Se citaron 11 individuos a consulta y de estos, 7 fueron entrevistados. Cada consulta fue llevada a cabo por un audiólogo y un asistente de salud aliado.

Resultados: se registró un alto grado de satisfacción general tanto por parte de los pacientes ( $87.3 \%$ excelente) como por el asistente de salud aliado (74.4\% excelente), mientras que el audiólogo proporcionó consistentemente niveles de satisfacción ligeramente más bajos ( $72.7 \%$ bueno). También se detectó que el audiólogo sugiere que la teleaudiología aumenta la calidad de la atención ofrecida.

Conclusión: Al examinar las perspectivas de todas las partes clave interesadas, este estudio identifica una serie de nuevos aspectos positivos y negativos de una práctica de teleaudiología y ofrece sugerencias para la implementación futura de dicho programa.

Palabras clave: cliente • clínico • satisfacción • teleaudiología • telesalud

\section{УРОВЕНЬ УДОВЛЕТВОРЁННОСТИ ВРАЧЕЙ И ПАЦИЕНТОВ КАЧЕСТВОМ ТЕЛЕ-АУДИОЛОГИЧЕСКИХ КОНСУЛЬТАЦИЙ}

\begin{abstract}
Аннотация
Вступление: До сих пор освоение телемедицины в Австралии было на удивительно низком уровне, а её применение было редким. Касается это в основном аудиологии. Данное исследование было направлено на проверку уровня удовлетворённости врачей и пациентов качеством телеаудиологических консультаций.

Материалы и методы: использована смешанная модель исследований, которая включала анкетирование для всех участников консультаций, а также частично структурированные интервью с пациентами после консультаций. В консультациях приняло
\end{abstract}


участие одиннадцать пациентов; интервью были проведены с семерыми пациентами. Каждая консультация проводилась одним аудиологом и одним медицинским помощником.

Результаты: В целом высокий уровень удовлетворённости отмечали пациенты (87,3\% - отличный результат) и медицинские помощники (74,4\% - отличный результат), тогда как аудиологи указывали несколько низший уровень удовлетворённости (72,7\% - хороший результат). Также было установлено, что аудиологи считают, что телеаудиология повышает качество медицинской помощи.

Выводы: Анализируя мнения всех ключевых заинтересованных сторон, данное исследование выявляет ряд новых положительных и негативных аспектов телеаудилогической практики и выдвигает некоторые предложения относительно будущей реализации такой программы.

Ключевые слова: пациент • врач • удовлетворённость • телеаудиология • телемедицина.

\section{SATYSFAKCJA LEKARZY I PACJENTÓW Z KONSULTACJI TELE-AUDIOLOGICZYCH}

\section{Streszczenie}

Wstęp: Do tej pory rozumienie tele-zdrowia w Australii było na zaskakująco niskim poziomie a jego zastosowanie miało charakter sporadyczny. Dotyczy to w szczególności audiologii. Niniejsze badanie miało na celu sprawdzenie zadowolenia lekarzy i pacjentów z konsultacji tele-audiologicznych.

Materiał i metody: Wykorzystano model badań mieszanych obejmujący ankiety dla wszystkich uczestników konsultacji oraz częściowo ustrukturalizowane wywiady pokonsultacyjne z pacjentami. W konsultacjach uczestniczyło jedenastu pacjentów; z siedmioma przeprowadzono wywiady. Każdą konsultację przeprowadzał jeden audiolog i jeden asystent medyczny.

Wyniki: Ogółem wysoki poziom zadowolenia uzyskali zarówno pacjenci (87,3\% doskonały wynik) jak i asystenci medyczni (74,4\% doskonały wynik), natomiast audiolodzy konsekwentnie uzyskiwali nieco niższy poziom zadowolenia (72,7\% dobry wynik). Stwierdzono również, że audiolodzy uważają, że tele-audiologia zwiększa jakość oferowanej opieki zdrowotnej.

Wnioski: Analizując opinie wszystkich najważniejszych osób biorących udział w niniejszym badaniu, należy stwierdzić, że zwraca ono uwagę na szereg nowych pozytywnych i negatywnych aspektów praktyki tele-audiologicznej i oferuje pewne propozycje dotyczące przyszłego wdrażania takiego programu.

Słowa kluczowe: pacjent • lekarz • zadowolenie • tele-audiologia • tele-zdrowie

\section{Background}

Australia's population is unevenly distributed, with $29 \%$ of people living in regional or remote areas [1]. Those dwelling in these areas experience poorer access to good health care compared to those living in major cities $[2,3]$. Of these people experiencing difficulty accessing services, $45 \%$ report the primary reason as waiting too long or failing to obtain an appointment in the time required, while $35 \%$ reported either no, or inadequate, services in their area [4].

Telehealth is emerging as a viable option for addressing the issue of access to services in more remote areas. Telehealth is defined as the use of telecommunication services for the provision of various healthcare services over a distance, and focuses on the transmission of data rather than the moving of patients and healthcare professionals [5]. This mode of service delivery is currently being utilised in varying capacities within both allied health and medicine to provide services including general consultations, diagnostic assessments, rehabilitation, treatments, training, and education [6-14].

Telehealth has been suggested as a feasible means of delivering audiological services remotely [15-19]. A systematic review conducted in 2015 by Blamey, Blamey, and Saunders [15] described an increase in the use of telehealth resources in the areas of speech, language, and hearing disorders for remote screening, assessment, intervention, and education. The review included 33 papers on hearing, with the main finding being that $93 \%$ of these papers attributed a benefit due to telehealth through better access to care, while cost-effectiveness was reported by $21 \%$ of the papers [20]. Telehealth has been trialled in a wide range of audiological services across all age groups. Swanepoel and Hall [19] conducted a systematic review of telehealth applications in audiology and found that many forms of audiological assessment, such as otoscopy, pure-tone and immittance audiometry, otoacoustic emissions, and auditory brainstem response (ABR) were viable when conducted through telehealth, with no clinically significant differences in results compared to face-to-face administration of these tests. This review also described positive results for satisfaction with hearing aid performance when fitted via telehealth (however, it should be noted that this conclusion was based upon a single hearing aid related study included in the review). Later, Campos and Ferrari confirmed that teleconsultation can be an efficient means of hearing aid programming, verification, and fitting when face-to-face services are not available [21]. Contemporary literature around teleaudiology has been addressing both new applications and the refinement of existing ones whilst also spanning a broader spectrum of services within the scope of audiological practice [22].

\section{Patient satisfaction with telehealth}

Telehealth is still in its infancy within the field of audiology and, as such, there is limited research regarding patient satisfaction with telehealth services. It has been trialled and implemented in other areas of allied health care, however, and results overall indicate clients were satisfied with the services they received $[6,10,14,20]$.

Kairy et al. conducted a study that explored patients' perceptions regarding telerehabilitation services following total knee replacement $(n=5)$ [10]. Patients reported many benefits to the program with a strong focus on reduction 
of travel, a major factor when considering their reduced mobility following surgery. Additionally, clients described the forming of a positive bond with their physiotherapist, saying they felt as though the therapist was in the room with them. Overall, the telerehabilitation experience for these physiotherapy patients was positive, although, due to the small sample size, the study does not provide strong evidence on satisfaction.

Patient satisfaction with telehealth has also been largely positive within occupational therapy $[6,14]$ and speechlanguage therapies [20]. Nonetheless, despite the increasing body of literature of predominantly positive patient satisfaction with telehealth, $17 \%$ of occupational therapy patients in a study by Worboys et al. indicated that they would still prefer a traditional consultation with a therapist, irrespective of the drawbacks of cost and inconvenience [14]. This finding is not anomalous, with similar reports noted in other telehealth studies [23].

\section{Patient satisfaction with audiologic practices via telehealth}

The current literature on patient satisfaction with audiologic services provided by telehealth has largely focused on their satisfaction with the outcome of the appointment for example, their satisfaction with the fitted hearing aids or mapped cochlear implant. Extremely limited research exists exploring their satisfaction with the appointment experience. Although it has been suggested that a strong link exists between client satisfaction with hearing aids and satisfaction with the services provided [24], it should not be assumed that this relationship holds for services provided using telecommunication.

In 2016, Ramkumar et al. explored parents' perceptions regarding a community-based screening program conducted with real-time telediagnostic testing [25]. Their findings showed generally positive perceptions, aside from when connection difficulties arose. Some apprehensions were attributed to the ABR testing and associated equipment, rather than the telehealth component. Another interesting finding of this paper was that, given the option of having hospital-based assessment or telehealth, only 1 of 87 interviewed participants preferred testing at the hospital.

\section{Practitioner satisfaction with telehealth}

Successful implementation of any new practice needs to address not only client satisfaction but also the satisfaction of the practitioners involved. Practitioner dissatisfaction has been associated with increased time pressure, lack of autonomy, and patient anger, as well as higher rates of illness, burnout, and job turnover [26,27]. Some research also suggests that higher patient satisfaction can result from more satisfied practitioners [28]. However, little research has been conducted in this area. The limited research does however show that, overall, audiologists and other hearing healthcare workers have positive attitudes towards telehealth, including views that using telehealth would have minimal influence on the quality of care or the quality of the interaction between practitioner and patient [29]. Interestingly though, another survey found that despite practitioners being familiar with and willing to use the technology, less than one-quarter had adopted it for consultations [30].

This study aims to investigate the feasibility of operating a comprehensive rehabilitative teleaudiology service, and addresses the attitudes and satisfaction of both clients and clinicians involved in teleaudiology appointments. It is anticipated that the results will provide suggestions for the implementation of future teleaudiology programs, maximising the benefits received by clients.

\section{Material and methods}

\section{Study design}

The current research was approved by the University of Queensland Human Research Ethics Committee (EC00457, approval \#2017000252). A mixed-methods study design was carried out seeking to understand the perspectives of clients and practitioners regarding teleaudiology. Using a mixed-methods approach in a complementary way allows the researcher to conduct in-depth research and provides a more meaningful interpretation of the data and the phenomenon being examined [31]. The study involved two simultaneously run phases: the first consisting of pre- and post-teleaudiology appointment surveys; and the second, semi-structured interviews with selected clients. All participation was voluntary. As a matter of disclosure, the third author of the current paper is the owner/director and principal audiologist of Hear Check (the private audiology company through which all data collection occurred).

\section{Selection of participants}

Phase 1. Participants of Phase 1 comprised three categories: client, audiologist, or allied health assistant (AHA). Convenience sampling was implemented for clients whereby, after making contact with Hear Check, they were given the option of a standard appointment or to participate in the teleaudiology trial. Audiologists on staff at the clinic fulfilled the role of audiologist or AHA. To avoid selection bias, all clients making contact with the clinic were invited to participate in the research project by the clinic's receptionist. Clients expressing interest were provided with information sheets and a written consent form, and were given one week to consider their involvement in the project. Any individuals with reading difficulties were given the opportunity to have information provided to them verbally by a member of the research team or family member. For paediatric appointments, parents were to provide the responses. Participants were finally asked to explain, in their own words, the nature of their involvement in the project, ensuring informed consent.

Phase 2. Phase 2 of the study employed convenience sampling. Those who had completed a teleaudiology appointment with Hear Check were invited to participate in a semi-structured interview further detailing their experience. Verbal consent was sought prior to commencement of the interviews. 


\section{Participant characteristics}

Survey results were received for a total of 11 teleaudiology appointments, each resulting in four surveys being completed: one each from the client, the audiologist, and the AHA following the appointment, as well as a pre-appointment survey from the client. Three of the 11 participants were male and the mean age of participants was $48 \mathrm{y}(\mathrm{SD}=30.71)$, median $=70 \mathrm{y}$, ranging between 4 and $74 \mathrm{y}$. Five $(45.5 \%)$ of the appointments were private clients while the remaining six (54.5\%) were seen under the Australian Government Hearing Services Program. A range of appointment types were carried out consisting of initial tests (7), follow-ups (1), annual reviews (2), and device adjustment (1). Three clients $(27.3 \%)$ had either not commenced schooling yet or were still in primary school and, consequently, their parents/guardians responded on their behalf. The semi-structured interviews forming Phase 2 of the study involved 7 of the original 11 surveyed clients.

\section{Materials}

\section{Surveys}

The four survey types used in Phase 1 depended on the classification of the participant (client, AHA, or audiologist) and were developed by the project's research assistants. The Pre-appointment Teleaudiology Questionnaire (Appendix A) was completed by clients and addressed issues of previous telehealth experience and expectations for the upcoming appointment. Following their appointment, clients completed the Hear Check Telehealth Client Survey (Appendix B). This included a series of 4-point Likert-scale based questions addressing satisfaction with various elements of the appointment, as well as two open-ended questions on the perceived benefits of the service and any changes recommended by the client. The AHA and audiologist completed similar Likert-based surveys geared towards their respective roles following each appointment (Appendix C and D). The survey for audiologists also included an additional series of 7-point Likert items adapted from Singh et al. (2014), which explored the attitudes of practitioners towards teleaudiology. Likert-scale based questionnaires were selected for familiarity among different participant types.

\section{Interview topic guide}

The researchers developed an interview guide for the semistructured interviews (Appendix E), with topics aimed at further extracting the experience of clients both in the lead up to, and during, the teleaudiology appointment. Questions were selected through team collaboration with the aim of neutrality, without introducing bias. Questions were then amended following two pilot interviews.

\section{Procedure}

\section{Audiological appointments}

The teleaudiology appointments were of the synchronous type and involved an audiologist at the Hear Check local office (Maroochydore, Queensland, Australia), with the AHA and client being at the remote location (Brightwater, Queensland) which was an existing remote site for Hear
Check. Depending on the type of the appointment, the equipment used may have included a video otoscope, an audiometer, tympanometer, and other software or hardware for the fitting or programming of hearing aids. The technology used to facilitate the telehealth aspect of the appointments consisted of a proprietary hardware and software combination. This allowed for both video conferencing and virtual network control of the computer at the remote site. This technology has been developed to minimize common pitfalls of similar technology, such as timing mismatch between audio and video. All software was encrypted to ensure the highest degree of patient privacy and data security.

\section{Survey data}

Prior to their appointment, participants were asked to complete an online questionnaire relating to their experience with telehealth and their expectations for the appointment. A period of one week after their appointment was given to complete a second questionnaire relating to their experience with the appointment. Audiologists and AHAs completed their respective surveys immediately following the completion of each appointment they were involved in. Participating Hear Check staff were unable to view client responses until the completion of the project, at which point only de-identified group data were accessible. Responses of all post-appointment surveys were placed in sealed envelopes.

\section{Interview data}

Individual semi-structured interviews were conducted with participants via telephone or video conference, as preferred by the participant. Interviews were conducted by a member of the research team; audiologists involved in the telehealth appointment were not permitted to interview the client. Interviews consisted of mostly open-ended questions following the developed topic guide. A time-frame of one week was set following the interview for any participant to contact the research team to provide any additional information or alter information previously provided.

\section{Data analysis}

\section{Survey data}

Data from the various surveys was coded from Likertbased questions and inputted into IBM SPSS 23 for frequency distribution analysis. The database was screened for any input errors or irregularities. A series of MannWhitney $U$ tests, using an exact sampling distribution, were performed to determine if there were any significant differences in overall satisfaction between client variables. The analysis of the limited number of open-ended questions was approached in a deductive manner of content analysis whereby the questions formed the basis for the development of themes.

\section{Interview data}

Participants' answers to the open-ended interview questions were thematically analysed over multiple stages following the de-identification of transcripts. Researchers immersed themselves in the text for familiarization which led to the generation of initial codes. The codes were then 
compiled to form overarching themes within the text. Themes were reviewed and adjusted following further reading of the text and coding was revisited with developed themes in mind. Thematic analysis was performed using MS Excel spreadsheets by Hear Check employees (not those who had seen participants); however, this was overseen by the University of Queensland to avoid potential bias in interpretation. The verbatim quotes below are referenced with the participant identifier (P1, P2, etc.).

\section{RESULTS}

\section{Phase 1}

The pre-appointment survey completed by clients showed that $8 / 11$ participants $(73 \%)$ had previous experience with telehealth services. Participants were asked to rate, on a 5-point scale, their feelings towards having their appointment conducted via telehealth. Ten of the 11 participants $(91 \%)$ either indicated they were happy or very happy to do so, whereas the remaining client indicated they would prefer a face-to-face appointment.

Table 1 displays response frequencies for the post-appointment client survey. Overall, clients' ratings for the various

Table 1. Count (\%) of client satisfaction ratings with teleaudiology appointment

\begin{tabular}{|c|c|c|c|c|}
\hline Question & Poor & Fair & Good & Excellent \\
\hline $\begin{array}{l}\text { 1. The voice quality of } \\
\text { the equipment }\end{array}$ & $0(0)$ & $0(0)$ & $1(9.1)$ & $10(90.9)$ \\
\hline $\begin{array}{l}\text { 2. The visual quality } \\
\text { of the equipment }\end{array}$ & $0(0)$ & $0(0)$ & $1(9.1)$ & 10 (90.9) \\
\hline $\begin{array}{l}\text { 3. Your personal } \\
\text { comfort in using } \\
\text { the teleaudiology } \\
\text { system }\end{array}$ & $0(0)$ & $0(0)$ & $3(27.3)$ & $8(82.7)$ \\
\hline $\begin{array}{l}\text { 4. The ease of } \\
\text { getting to the } \\
\text { teleaudiology } \\
\text { department }\end{array}$ & $0(0)$ & $0(0)$ & $2(18.2)$ & 9 (81.8) \\
\hline $\begin{array}{l}\text { 5. The length of } \\
\text { time with the } \\
\text { Audiologist }\end{array}$ & $0(0)$ & $0(0)$ & $2(18.2)$ & 9 (81.8) \\
\hline $\begin{array}{l}\text { 6. The explanation of } \\
\text { your appointment } \\
\text { by the Hear Check } \\
\text { team }\end{array}$ & $1(9.1)$ & $0(0)$ & $0(0)$ & $10(90.9)$ \\
\hline $\begin{array}{l}\text { 7. The thoroughness, } \\
\text { carefulness and } \\
\text { skilfulness of the } \\
\text { Hear Check team }\end{array}$ & $0(0)$ & $0(0)$ & $1(9.1)$ & $10(90.9)$ \\
\hline $\begin{array}{l}\text { 8. The courtesy, } \\
\text { respect, sensitivity } \\
\text { and friendliness } \\
\text { of the Hear Check } \\
\text { team }\end{array}$ & $0(0)$ & $0(0)$ & $1(9.1)$ & $10(90.9)$ \\
\hline $\begin{array}{l}\text { 9. How well your } \\
\text { privacy was } \\
\text { respected }\end{array}$ & $0(0)$ & $0(0)$ & $1(9.1)$ & $10(90.9)$ \\
\hline $\begin{array}{l}\text { 10. How well the staff } \\
\text { answered your } \\
\text { questions about } \\
\text { the equipment }\end{array}$ & $0(0)$ & $0(0)$ & $1(9.1)$ & $10(90.9)$ \\
\hline Total & $1(0.9)$ & $0(0)$ & $13(11.8)$ & $96(87.3)$ \\
\hline
\end{tabular}

components of the appointment were very positive with $87 \%$ indicating excellent levels of satisfaction. The client survey also contained two open-ended questions asking for comments on what was liked and disliked about the appointment. Although few changes to the appointments were suggested, two participants commented on unnecessary noise being present during the appointment, both internal echoes in the testing room and background noise outside the room. Nine of the 11 participants commented on the perceived benefits of the appointment, with themes being the ability to test closer to their home $(n=5)$ and being more aware of the results $(n=3)$.

A series of Mann-Whitney $U$ tests, using an exact sampling distribution, were performed to determine if there were any significant differences in overall satisfaction between private and publicly-funded clients, males and females, and those with and without experience in telehealth services. Clients' overall satisfaction was calculated by finding the median of each client's total ratings across 10 questions. Distributions for the clients' median satisfaction between all groups were similar, as assessed by visual inspection. No significant difference was found in these group comparisons $(p>0.05)$.

Table 2. Count (\%) of allied health assistant satisfaction ratings with teleaudiology appointment

\begin{tabular}{|c|c|c|c|c|}
\hline Question & Poor & Fair & Good & Excellent \\
\hline $\begin{array}{l}\text { 1. The Audiologist's } \\
\text { ability to } \\
\text { communicate with } \\
\text { the client }\end{array}$ & & $0(0)$ & $0(0)$ & 9 (81.8) \\
\hline $\begin{array}{l}\text { 2. The client's ability } \\
\text { to communicate } \\
\text { with the Audiologist }\end{array}$ & $0(0)$ & $0(0)$ & $3(27.3)$ & $8(72.7)$ \\
\hline $\begin{array}{l}\text { 3. The voice quality of } \\
\text { the equipment }\end{array}$ & $0(0)$ & $0(0)$ & $0(0)$ & $11(100)$ \\
\hline $\begin{array}{l}\text { 4. The visual quality of } \\
\text { the equipment }\end{array}$ & $0(0)$ & $0(0)$ & $0(0)$ & $11(100)$ \\
\hline $\begin{array}{l}\text { 5. The adequacy } \\
\text { of telehealth } \\
\text { as a method of } \\
\text { service delivery in } \\
\text { audiology }\end{array}$ & $0(0)$ & $0(0)$ & $3(27.3)$ & $8(72.7)$ \\
\hline $\begin{array}{l}\text { 6. Your personal } \\
\text { comfort in using } \\
\text { the teleaudiology } \\
\text { system }\end{array}$ & $0(0)$ & $0(0)$ & $6(54.5)$ & $5(45.5)$ \\
\hline $\begin{array}{l}\text { 7. Your level of } \\
\text { comfort and } \\
\text { confidence in } \\
\text { your abilities to } \\
\text { assist the delivery } \\
\text { of services of } \\
\text { the same quality } \\
\text { as face-to-face } \\
\text { appointments }\end{array}$ & $0(0)$ & $0(0)$ & $4(36.4)$ & $7(63.6)$ \\
\hline $\begin{array}{l}\text { 8. The length of time } \\
\text { spent with the client }\end{array}$ & $0(0)$ & $0(0)$ & $4(36.4)$ & $7(63.6)$ \\
\hline $\begin{array}{l}\text { 9. The client's } \\
\text { satisfaction and } \\
\text { enjoyment of the } \\
\text { service }\end{array}$ & $\begin{array}{c}2 \\
(18.2)\end{array}$ & $0(0)$ & $1(9.1)$ & $8(72.7)$ \\
\hline Total & $4(4.1)$ & $0(0)$ & $21(21.2)$ & 74 (74.7) \\
\hline
\end{tabular}


Results indicating the allied health assistant (AHA) satisfaction ratings are shown in Table 2. 'Excellent' ratings were given in $74.4 \%$ of responses. Open-ended responses indicated that on two occasions difficulties in communication between the audiologist and child arose, whereby the child would only speak to the AHA, and not to the audiologist on the screen. One appointment was reported to run over time due to complexities of the case; however, it is unclear whether this was directly attributable to the telehealth method. In another appointment, the AHA reported that due to the severity of the client's hearing loss, she had to convey all information to the unaided client as the audiologist could not be heard.

Tables 3 and 4 show the audiologist's ratings of satisfaction for the two sections of their survey. Section 1 asked similar questions to the other satisfaction surveys. Although no element of the appointment resulted in poor ratings from the audiologist, only $25 \%$ of the total responses were rated excellent. Section 2 of the audiologist's survey rated how the delivery of audiological services via telehealth affected key areas of the appointment when compared to their prior experience of face-to-face appointments. The most frequent responses to each question in Table 4 are shaded and indicate quality of care to be slightly increased; no effect on the quality of interaction or relationship between practitioner and client; a slightly decreased ability to discuss private topics with clients; a greatly increased ability to conduct urgent appointments, and a slight increase in the need for technological troubleshooting.

Six questions in the three post-appointment surveys were common between either all three surveys or in both the audiologist's and the AHA's version. A comparison of the median scores as rated by each type of respondent is shown in Table 5. Results clearly show clients and the AHA generally rating a 4 (excellent), compared to the audiologist's rating of 3 (good). Exceptions were that both the audiologist and the AHA rated equal levels of satisfaction for their comfort in using the system and the time spent with the client.

\section{Phase 2}

The second phase of the study involved semi-structured interviews with 7 of the 11 Phase 1 clients. Three topical categories were identified that encompassed the clients' experiences of being involved in a teleaudiology appointment: (1) technology; (2) implications of the test environment;

Table 3. Count (\%) of audiologist satisfaction ratings with teleaudiology appointment

\begin{tabular}{|c|c|c|c|c|}
\hline Question & Poor & Fair & Good & Excellent \\
\hline 1. Your ability to communicate with the client & $0(0)$ & $0(0)$ & $7(63.6)$ & $4(36.4)$ \\
\hline 2. The voice quality of the equipment & $0(0)$ & $1(9.1)$ & $7(63.6)$ & $3(27.3)$ \\
\hline 3. The visual quality of the equipment & $0(0)$ & $0(0)$ & $11(100)$ & $0(0)$ \\
\hline 4. The adequacy of telehealth as a method of service delivery in audiology & $0(0)$ & $0(0)$ & $5(45.5)$ & $6(54.5)$ \\
\hline $\begin{array}{l}\text { 5. Your level of comfort and confidence in your abilities to deliver services of the same } \\
\text { quality as traditional face-to-face appointments }\end{array}$ & $0(0)$ & $0(0)$ & $10(90.9)$ & $1(9.1)$ \\
\hline 6. The length of time spent with the client & $0(0)$ & $0(0)$ & $5(45.5)$ & $6(54.5)$ \\
\hline 7. Your personal comfort in using the teleaudiology system & $0(0)$ & $0(0)$ & $10(90.9)$ & $1(9.1)$ \\
\hline 8. The client's satisfaction and enjoyment of the service & $0(0)$ & $1(9.1)$ & $9(81.8)$ & $1(9.1)$ \\
\hline Total & $0(0)$ & $2(2.3)$ & $64(72.7)$ & $22(25)$ \\
\hline
\end{tabular}

Table 4. Count (\%) of audiologist ratings of telehealth service delivery vs face-to-face appointment

\begin{tabular}{|c|c|c|c|c|c|c|c|}
\hline & 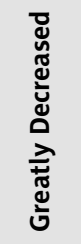 & 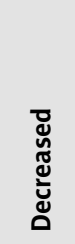 & 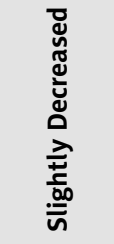 & 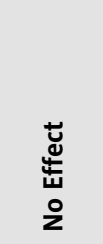 & 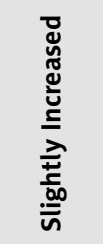 & 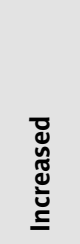 & 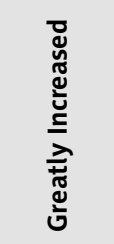 \\
\hline The quality of care in audiology & $0(0)$ & $0(0)$ & $0(0)$ & $3(27)$ & $8(73)$ & $0(0)$ & $0(0)$ \\
\hline $\begin{array}{l}\text { The quality of the interaction between the patient and the } \\
\text { practitioner }\end{array}$ & $0(0)$ & $0(0)$ & $1(9)$ & $10(91)$ & $0(0)$ & $0(0)$ & $0(0)$ \\
\hline $\begin{array}{l}\text { The quality of the relationship between practitioners and new } \\
\text { clients }\end{array}$ & $0(0)$ & $0(0)$ & $0(0)$ & $10(91)$ & $1(9)$ & $0(0)$ & $0(0)$ \\
\hline $\begin{array}{l}\text { The ability to discuss potentially private or embarrassing } \\
\text { topics with clients }\end{array}$ & $0(0)$ & $0(0)$ & $11(100)$ & $0(0)$ & $0(0)$ & $0(0)$ & $0(0)$ \\
\hline The ability to quickly meet with clients for urgent appointments & $0(0)$ & $0(0)$ & $0(0)$ & $0(0)$ & $0(0)$ & $0(0)$ & $11(100)$ \\
\hline The need for technological troubleshooting & $0(0)$ & $0(0)$ & $0(0)$ & $3(27)$ & $7(64)$ & $1(9)$ & $0(0)$ \\
\hline Total & $0(0)$ & $0(0)$ & $12(18)$ & $26(39)$ & $16(24)$ & $1(2)$ & $11(17)$ \\
\hline
\end{tabular}


Table 5. Median satisfaction ratings for common survey questions

\begin{tabular}{|c|c|c|c|c|c|c|}
\hline \multirow[t]{2}{*}{ Questions } & \multicolumn{2}{|c|}{ Client } & \multicolumn{2}{|c|}{ Audiologist } & \multicolumn{2}{|c|}{ AHA } \\
\hline & Median & Range & Median & Range & Median & Range \\
\hline Voice quality of appointment & 4 & 1 & 3 & 2 & 4 & 0 \\
\hline Visual quality of appointment & 4 & 1 & 3 & 0 & 4 & 0 \\
\hline Length of time spent between audiologist and client & 4 & 1 & 4 & 1 & 4 & 1 \\
\hline Personal comfort using teleaudiology system & 4 & 1 & 3 & 1 & 3 & 1 \\
\hline $\begin{array}{l}\text { Level of comfort and confidence in delivery of services of the same quality } \\
\text { as traditional face-to-face appointments }\end{array}$ & NA & NA & 3 & 1 & 4 & 1 \\
\hline Audiologist's ability to communicate with client & NA & NA & 3 & 1 & 4 & 3 \\
\hline
\end{tabular}

4 = Excellent, 3 = Good, 2 = Poor, 1 = Fair, NA = Not Applicable

and (3) the perceived differences between their appointment and face-to-face consultations. Thematic analysis and response examples for each category are presented below.

\section{Category 1: Technology}

\section{A) Positive associations With THE TeChNology $(N=20$ RESPONSES FROM 7 PARTICIPANTS $)$}

All clients were extremely impressed with the audio, visual, and connection aspects of the technology utilised. Many made statements describing their surprise in the quality; for example,

I thought it was very good, to be honest. I was actually really surprised. The quality of the image was so good, and the sound was really good. (P5)

Four clients described having experience with tele-conferencing for work or communicating with overseas family. These clients made statements comparing the service experienced in their appointment to other services, particularly their use of Skype; for example,

Those previous ones, sometimes they drop in and out. I thought that was very smooth, and there were no, you know when you're on the internet sometimes there's a slight delay, and there didn't seem to be any of that. (P1)

\section{B) Negative associations With technology USED ( $N=7$ FROM 2 PARTICIPANTS)}

Despite being impressed with the quality of technology employed, one client raised concerns around the accuracy of the testing when technical difficulties occurred:

It made me feel a lack of confidence about the technology... whether or not that was actually working, I guess... It made me feel a bit uncertain about the rest of the test. (P5)

Another participant, a client with a cochlear implant, described feeling uncomfortable because of seeing themselves on the AHA's computer screen.

P6: The only thing I don't like is, I don't like my face coming up over there.
Interviewer: Oh, you didn't like seeing yourself?

P6: Well, seeing what they see. (P6)

\section{C) Considerations FOR CHILDREN $(N=2$ FROM 2 PARTICIPANTS)}

Two of the participants interviewed were representing their young children and both provided statements regarding the effect their children's previous level of exposure to video conferencing had on the appointment:

Yeah. And for my daughter she hasn't experienced talking to somebody on the computer before. (P4)

It was like that kind of setting, although I have to say, because I've got family abroad, she uses Skype, so she's used to seeing someone on the screen talking to her. (P5)

\section{Category 2: Implications of the test environment}

\section{A) EFFECT OF TRIAL ENVIRONMENT $(N=8$ FROM 3 PARTICIPANTS)}

Clients were aware of participating in a trial for a teleaudiology practice. Some participants referred to this fact; for example:

Yeah, it seemed a lot more rushed. Maybe it was because of the trial setting as well... It was a bit (unstructured). (P5)

I suppose if it was happening for real, then I would probably ask more questions about the issue that was wrong. (P1)

\section{B) COMPETENCY OF STAFF $(N=7$ FROM 3 PARTICIPANTS)}

The training of staff and, consequently, the competency of staff in the use of technology being employed, was raised as a potential detractor from appointment experience:

Yes, I think that's really important, because if the audiologist is trying to fix the technology when the patient is in the room and seems uncertain about 
what's going on, then I think the patient loses confidence in the process. (P5)

\section{C) Clinic room properties $(N=13$ From 6 PARTICIPANTS)}

Comments were made by participants regarding test room size, reverberance, and set up.

Obviously depending on where you're running it throughout the country, the size of the room is going to be different and the layout of the room is going to be different. The only thing was that [child] was sitting on the chair in front of the computer and the keyboard was in front and then [AHA] was having to lean over [child] to type into the keyboard. (P4)

But there was a problem with the room. It was not a good room. It was very echoey. (P8)

One participant also commented on the unsuitability of the waiting room:

Because there wasn't really a (facility) to have a four-year-old sitting impatient and making noise and carrying on next door, we were asked by [AHA], very definitely, you get the idea she wanted us to go away, come back later. Obviously, I would say the (facilities) were not ideal... (P5)

Category 3: Differences between teleaudiology and face-to-face appointments

\section{A: NO DIFFERENCE BETWEEN APPOINTMENT TYPES $(N=10$ FROM 4 PARTICIPANTS $)$}

Four clients reported no difference between their teleaudiology appointment and other appointment modes; for example:

Interviewer: And just to clarify, you've said "successful" a number of times, but how are you measuring that as a successful appointment? What factors did you consider? P2: Well, I was probably comparing it to what would happen in a normal consultation. (P2)

Well, apart from the fact that I had somebody on the screen and somebody doing a physical part of it, it wasn't all that different. (P2)

The only difference is sitting in front of a person versus sitting in front of a screen. (P4)

\section{B) Tele-based PRACtices aren't as PERSONAL $(N=6$ FROM 5 PARTICIPANTS $)$}

Two clients expressed preference for a face-to-face appointment due to the lack of personalisation.

Interviewer: Do you feel anything was different?
P8: Yeah, obviously, yeah. It totally lacks that interaction process and the comfort. Not that [AHA] made me feel uncomfortable, in no way did that happen. Just the face-to-face is so much better. (P8)

Interviewer: So, can you tell me what you found was, I guess, less personal about the appointment?

P4: I don't know, just not having that person in the room I suppose. (P4)

One client described his concerns regarding continuity of care when using this model of appointment:

Because it was someone else doing the appointment, it looked like she hadn't read the file properly, and so she was asking me a lot of questions which were already or should have been addressed in the notes. So there was a certain amount of repetition, which was fine. I didn't mind, I just think that, it for me, raised questions about continuity of care. (P5)

\section{C) Benefits of TEle-BASEd PRACTICES $(N=11$ FROM 4 PARTICIPANTS)}

Several participants described the benefits teleaudiology appointments might bring to the target clientele, those living further out from major cities. One participant, with extensive experience previously living in rural areas, said:

I was really happy with the way it went, and if I was living in the bush, it would certainly beat driving into a major city to have your hearing test done and so forth. I felt quite comfortable, that it was extremely successful. (P2)

In addition to reducing distance for clients to travel, other participants reported feeling more involved in the appointment.

Interviewer: So how did you find this appointment was compared to a face-to-face appointment?

P8: Probably no real difference actually. But, the only... The big difference was I could see what was going on. That I could see more of what was going on than what I would see in the normal hearing (test). (P8)

I thought it was interesting because it's not something that we normally see. So yeah, educational I suppose. (P4)

\section{Discussion}

The present study investigated the satisfaction of clients and practitioners involved in teleaudiology appointments. Survey data showed high satisfaction in all participant groups, although the audiologist consistently provided lower levels of satisfaction for the appointments compared to the clients and the AHA. Participants reported effects of the technology used, the testing environment, and the staff involved. Due to the nature of the study, being based on 
a trial implantation of a tele-audiology program, recommendations for future practice were also made by clients.

\section{Client satisfaction}

Clients' ratings of satisfaction for their appointments were largely positive with $87.3 \%$ of total responses rated as excellent. Most of the other, lower levels of satisfaction occurred across three particular questions and were rated as good: personal comfort in using the teleaudiology system; the ease of getting to the teleaudiology department; and the length of time with the audiologist. Falling outside the positive trend of results was one rating of poor satisfaction to the explanation of the appointment by the Hear Check team. Further discussion with this client revealed external factors in the home were the reason for this.

No significant differences were found in satisfaction levels between the tested group comparisons (i.e., funding source, gender, or telehealth experience). Despite these findings, there is still the possibility that ratings of satisfaction by clients were made based on previous experiences with audiology, telehealth, regional living experience, or prior use of video conferencing. Future research should use a larger sample size to better ascertain any differences, as well as gather increased demographic information for comparison purposes.

Also yielding largely positive views, interviews allowed for a richer understanding of the client's experiences. Three overarching categories from the semi-structured interviews were identified: (1) Technology (comprising positive and negative associations with it, as well as matters specifically pertaining to children); (2) Implications of the test environment (including effects of the trial nature of the program, competency of staff, and properties of the clinic room); and (3) Differences between teleaudiology and face-to-face appointments (consisting of positive, negative, and neutral comparisons).

Regarding technology, although the survey data showed overall positive client satisfaction with the technology, clients were quick to notice any difficulties and described losing confidence in the testing process. They attributed this loss of confidence to lack of competency of the staff when troubleshooting problems. This finding highlights that: a) richer data needs to be collected from participants; b) further training should be implemented for staff prior to engaging with new technology; c) participants naturally have high expectations of the level of care; and d) that technical problems associated with the internet provider tend to be attributed to the audiologist and/or equipment failure. Although only mentioned by one client, the discomfort experienced from visualising oneself on the screen is likely applicable to a significant proportion of people. Furthermore, two of three children tested were reported to have difficulties communicating with the audiologist. This finding is unique to this study, as no existing studies implemented in paediatric and pre-/school aged populations have considered the impact on the child.

Based on thematic analysis, an increase in future appointment length could be recommended, to accommodate unexpected technological difficulties and to prevent clients feeling rushed in their appointment. It may also help to build rapport between the audiologist and client, further encouraging the client to ask questions during the appointment. Increased appointment time would also decrease demands on the audiologist, reported previously to be the highest stress factor in healthcare workers [32]. However, such an increase may have economic consequences for the audiology department and, as such, further research in this area is certainly warranted. Other comments addressed the need for future practices to ensure rooms in each remote location are as suitable as possible for testing, as they are unlikely to have been purpose-built. However, all rooms used in the current investigation did meet maximum noise level requirements according to ANSI standards. Previous research has attributed benefits to telehealth, including increased access to care and cost effectiveness [20]. This study served to further explore these aspects, as well as to highlight any further benefits as perceived by the client. The increased access to care was supported by the participants, envisaging that when the service is fully implemented it could save clients' time. This is in addition to the potential for clinicians to see clients sooner and to reduce wait times, as has been previously explored [33].

Finally, clients made astute distinctions between the experienced telehealth appointment and face-to-face appointments. Many similarities were perceived, and in some cases the only difference was that there were two clinicians involved. However, five participants described the appointment as feeling less personal from not having the audiologist in the room. The time spent addressing problems with technology was also perceived to detract from the experience, with participants noting a greater deal of attention on the technology rather than the client. Conversely, some clients also reported an increased sense of being involved in the appointment. Overall, there appeared to be variability between clients feeling more involved and those perceiving a less personal appointment. Perhaps, given the fact an audiologist was acting as the AHA, they were more active or passive in different appointments. Previous research suggests that the AHA should be able to complement the attention given to the client, thus strengthening relationships in teleconsultations [34]. Future research should seek to uncover underlying variables that might improve client satisfaction with the psychosocial aspects of the teleaudiology appointment.

\section{Audiologist satisfaction}

The satisfaction of audiologists with teleaudiology appointments has only recently been explored and little is known. A study by Singh et al. found that, although the audiologists they surveyed had positive attitudes towards teleaudiology, very few, in fact, used it in practice [29]. Results of the present study revealed the audiologist had positive attitudes to some elements of teleaudiology while having reservations about others. Furthermore, Section 1 of the audiologist survey (Table 3) showed an overall lower level of satisfaction with areas of the appointment $(25 \%$ as excellent) when compared with the client's and AHA's perspectives, who rated it as excellent $(87.3 \%$ and $74.4 \%$ respectively). This lower level of satisfaction was uniform across individual questions. 
There are numerous possible reasons for this. Firstly, the audiologist may simply have higher expectations of the tele-equipment being utilised, especially as she was an employee where the trial took place. The change in the audiologist's routine may also have affected their ratings, a factor that previous research suggests could be offset with more extensive training [35]. Another possibility is that, given the higher ratings of satisfaction by the clients and the AHA, and given location differences, there may have been differences in the quality of sound and video at each site. Additionally, the client and the AHA still retained face-to-face contact, a factor which perhaps impacted on certain measures of satisfaction. Arguably, to perform their role in the appointment, the audiologist needs to adapt to a greater degree. Previous research has also suggested that, as teleaudiology becomes more widely adopted by hearing professionals, they may take a more positive view [29]. Finally, it has been stated previously that multiple factors - including the acceptance, preferences, individual perceptions of risks and benefits, as well as the perceived effectiveness and efficiency of the service - could affect the clinician's satisfaction [35].

The audiologist's perspective was further explored by comparing the rating for each appointment to their extensive experience in face-to-face appointments. Of particular interest was that conducting the appointment via telehealth had no impact on the quality of the interaction or the relationship between clinician and client, a finding in agreement with research by Singh et al. [29]. Unlike this previous research, however, the audiologist rated the overall quality of care offered to be slightly increased. This finding warrants further exploration, as results here only reflect a single audiologist's views. The audiologist definitely rated the ability to discuss private topics as being slightly decreased. This was attributed to the presence of the AHA, despite the AHA being bound by the same confidentiality rules as the audiologist. Although a concern of the audiologist here, previous telehealth research suggests that the ability to engage in private conversations is not a major concern of clients [36]. Finally, the audiologist rated the ability to conduct appointments at short notice as being greatly increased; however, this relies on a trained AHA being available. In more remote areas, such availability may need to be spread across several healthcare roles.

\section{Allied health assistant satisfaction}

This study deliberately included the perspectives of the AHA in the teleaudiology appointment. As a participating party in the appointment, it is important to investigate their perspective also, as it is a perspective missing from the current literature. For most of the questions asked, the AHA rated their satisfaction as excellent. The only question for which ratings were spread evenly between good and excellent, rather than being predominantly excellent, related to personal comfort in using the telehealth system. Although further research is needed to explore ways to improve comfort for staff during appointments, one suggestion would be to give more extensive training of the AHA for this role.

\section{Study limitations and future directions}

The findings represent only the sample involved, so it is unclear if the same findings would be obtained for the broader community, or indeed those living in other regional and rural areas. The clinicians involved in this study were both audiologists employed by the company administering the appointments, and so their levels of satisfaction might differ from that of other audiologists. Future research should include multiple audiologists, as well as multiple allied health assistants who are highly trained to fill their role in these appointments. A more extensive trial of this system should next be carried out with the AHA and the client in a rural town, over a longer distance and appointment length, to allow for a greater and more diverse sample.

\section{Conclusion}

With increasing demand on audiologists, and the need to see both regional and rural clients in a timely and costeffective manner, teleaudiology as explored in recent literature appears a viable option. With any new application of technology or services, however, it is important that the practice is validated in terms of clinical test results and the satisfaction of all involved measured. This study showed high levels of satisfaction from clients for most aspects, supporting the belief that such a service would greatly benefit those living outside capital cities. Similarly, high satisfaction was reported by the allied health assistant. From the perspective of the audiologist, the study also showed ways in which teleaudiology appointments could be improved, but it is clear that they do increase the quality of care offered.

\section{Acknowledgements}

The authors would like to thank the staff of Hear Check, Anthea Bott, Cerys Downing, and J. Watt, for their efforts in scheduling and conducting appointments, as well as their involvement in the collection of data.

\section{References}

1. Australian Institute of Health and Welfare. Australia's health 2016 - in brief [online] 2016 [cited 2017 April 28]. Available from: http://www.aihw.gov.au/publication-detail/?id=60129555545

2. Australian Institute of Health and Welfare. Rural health [online] 2015 [cited 2017 July 18]. Available from: http://www.aihw.gov. au/rural-health/

3. Lawrence G. Teleaudiology brings better hearing healthcare to Australia's outback. Hear J, 2012; 65(11).
4. Australian Bureau of Statistics. 4159.0 General social survey: Summary results, Australia, 2014 [online] 2015 [cited 2017 April 20]. Available from: http://www.abs.gov.au/AUSSTATS/abs@.nsf/Loo kup/4159.0Main+Features12014?OpenDocument

5. Australian Government Department of Health. Telehealth [online] 2015 [cited 2017 March 3]. Available from: http://www.health.gov. au/internet/main/publishing.nsf/Content/e-health-telehealth

6. Cason J. Telehealth: A rapidly developing service delivery model for occupational therapy. Int J Telerehabil, 2014; 6: 29-36. 
7. Edwards M, Stredler-Brown A, Houston KT. Expanding use of telepractice in speech-language pathology and audiology. Volta Rev, 2012; 112: 227-42.

8. Fabry D. Applications of telehealth for hearing care [online] 2010 [cited 2017 August 27]. Available from: www.audiology.org

9. Harrison R, Macfarlane A, Murray E, Wallace P. Patients' perceptions of joint teleconsultations: a qualitative evaluation. Health Expect, 2006; 9: 81-90.

10. Kairy D, Tousignant M, Leclerc N, Côté A-M, Levasseur M, et al. The patient's perspective of in-home telerehabilitation physiotherapy services following total knee arthroplasty. Int J Environ Res Publ Health, 2013; 10: 3998-4011.

11. Morales-Vidal S, Ruland S. Telemedicine in stroke care and rehabilitation. Top Stroke Rehabil, 2013; 20: 101-7.

12. Raven M, Butler C, Bywood P. Video-based telehealth in Australian primary health care: current use and future potential. Aust J Prim Health, 2013; 19: 283-6.

13. Tousignant M, Moffet H, Boissy P, Corriveau H, Cabana F, Marquis $\mathrm{F}$. A randomized controlled trial of home telerehabilitation for post-knee arthroplasty, J Telemed Telecare, 2011; 17: 195-8.

14. Worboys T, Brassington M, Ward EC, Cornwell PL. Delivering occupational therapy hand assessment and treatment sessions via telehealth. J Telemed Telecare, 2017; 185-92.

15. Blamey PJ, Blamey JK, Saunders E. Effectiveness of a teleaudiology approach to hearing aid fitting. J Telemed Telecare, 2015; 21: 474-8.

16. Eikelboom RH, Jayakody DMP, Swanepoel DW, Chang S, Atlas MD. Validation of remote mapping of cochlear implants. J Telemed Telecare, 2014; 20: 171-7.

17. Elliott G, Smith AC, Bensink ME, Brown C, Stewart C, Perry $\mathrm{C}$, et al. The feasibility of a community-based mobile telehealth screening service for Aboriginal and Torres Strait Islander children in Australia. Telemed J E Health, 2010; 16: 950-6.

18. Jacobs PG, Saunders GH. New opportunities and challenges for teleaudiology within Department of Veterans Affairs. J Rehabil Res Dev, 2014; 51: 7-12.

19. Swanepoel DW, Hall JW. A systematic review of telehealth applications in audiology. Telemed J E Health, 2010; 16: 181-200.

20. Regina Molini-Avejonas D, Rondon-Melo S, De La Higuera Amato CA, Samelli AG. A systematic review of the use of telehealth in speech, language and hearing sciences. J Telemed Telecare, 2015; $21: 367-76$.

21] Campos PD, Ferrari DV. Teleaudiology: evaluation of teleconsultation efficacy for hearing aid fitting. J da Sociedade Brasileira de Fonoaudiologia, 2012; 24: 301-8.
22] Krumm M. A review of contemporary tele-audiology literature. J Hear Sci, 2016; 6: 9-21.

23] Sharma S, Ward EC, Burns C, Theodoros D, Russell T. Assessing dysphagia via telerehabilitation: patient perceptions and satisfaction. Int J Speech Lang Pathol, 2013; 15: 176-83.

24. Dillon H, Birtles G, Lovegrove, R. Measuring the outcomes of a national rehabilitation program: normative data for the client oriented scale of improvement (COSI) and the hearing aid user's questionnaire (HAUQ). J Am Acad Audiol, 1999; 10: 67-79.

25. Ramkumar V, Selvakumar K, Vanaja CS, Hall JW, Nagarajan R, Neethi J. Parents' perceptions of tele-audiological testing in a rural hearing screening program in South India. Int J Pediatr Otorhinolaryngol, 2016; 89: 60-6.

26. Lipkin M, Schwartz M. I can't get no patient or practitioner satisfaction. J Gen Intern Med, 2000; 15: 140-1.

27. Suchman LA, Roter LD, Green LM, Lipkin LM. Physician satisfaction with primary care office visits. Med Care, 1993; 31: 1083-92.

28. Haas JS, Cook EF, Puopolo AL, Burstin HR, Cleary PD, Brennan TA. Is the professional satisfaction of general internists associated with patient satisfaction? J Gen Intern Med, 2000; 15: 122-8.

29. Singh G, Pichora-Fuller MK, Malkowski M, Boretzki M, Launer S. A survey of the attitudes of practitioners toward teleaudiology. Int J Audiol, 2014; 53: 850-60.

30. Eikelboom R, Swanepoel D. International survey of audiologists' attitudes toward telehealth. Am J Audiol, 2016; 25: 295-8.

31. Tashakkori A, Teddlie C. Handbook of mixed methods in social and behavioral research. Thousand Oaks, CA. SAGE; 2003.

32. Severn MS, Searchfield GD, Huggard P. Occupational stress amongst audiologists: compassion satisfaction, compassion fatigue, and burnout. Int J Audiol, 2012; 51: 3-9.

33. Hofstetter PJ, Kokesh J, Ferguson AS, Hood LJ. The impact of telehealth on wait time for ENT specialty care. Telemed J E Health, 2010; 16: 551.

34. Reginato TTP, Ferrari DV. Teleaudiology: professional-patient communication in hearing aid programming and fitting via teleconsultation. Audiol Commun Res, 2014; 19: 299-309.

35. Whitten P, Love B. Patient and provider satisfaction with the use of telemedicine: overview and rationale for cautious enthusiasm. J Postgrad Med, 2005; 51: 294-300.

36. Eikelboom RH, Atlas MD. Attitude to telemedicine, and willingness to use it, in audiology patients. J Telemed Telecare, 2005; 11: 22-5. 


\section{Appendix A: Pre-Teleaudiology Questionnaire}

\section{Hear Check}

living is hearing

\section{Pre- Teleaudiology questionnaire}

1) Have you had any experience with telehealth services previously (for example: specialist appointment through Skype)? Yes / No

If Yes please provide information on the service

2) How do you feel about having the appointment today via tele services (please circle your answer)?

Would much prefer to have appointment face to face
Would prefer to have appointment face to face

\section{Neutral (don't mind either way)}

\section{Happy to have service through telehealth}

Very happy to have service through telehealth

\section{Appendix B: Hear Check Telehealth Client Survey}

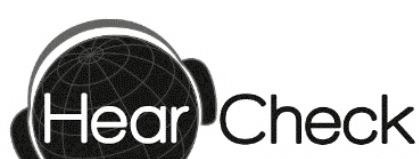

living is hearing

\section{Hear Check Telehealth Client Survey}

Thank you for attending the appointment today via teleaudiology. We are committed to continually developing this service. Your feedback is important to us and will assist us to improve our service.

\begin{tabular}{|c|c|c|c|c|c|}
\hline How satisfied were you with: & Excellent (4) & Good (3) & Poor (2) & Fair (1) & Not applicable (0) \\
\hline \multicolumn{6}{|l|}{ The voice quality of the equipment } \\
\hline \multicolumn{6}{|l|}{ The visual quality of the equipment } \\
\hline \multicolumn{6}{|l|}{$\begin{array}{l}\text { Your personal comfort in using the Teleaudiology } \\
\text { system }\end{array}$} \\
\hline \multicolumn{6}{|l|}{$\begin{array}{l}\text { The ease of getting to the teleaudiology } \\
\text { department }\end{array}$} \\
\hline \multicolumn{6}{|l|}{ The length of time with the Audiologist } \\
\hline \multicolumn{6}{|l|}{$\begin{array}{l}\text { The explanation of your appointment by the Hear } \\
\text { Check team }\end{array}$} \\
\hline \multicolumn{6}{|l|}{$\begin{array}{l}\text { The thoroughness, carefulness and skilfulness of } \\
\text { the Hear Check team }\end{array}$} \\
\hline \multicolumn{6}{|l|}{$\begin{array}{l}\text { The courtesy, respect, sensitivity and friendliness } \\
\text { of the Hear Check team }\end{array}$} \\
\hline \multicolumn{6}{|l|}{ How well your privacy was respected } \\
\hline $\begin{array}{l}\text { How well the staff answered your questions about } \\
\text { the equipment }\end{array}$ & & & & & \\
\hline
\end{tabular}




\section{Appendix C: Hear Check Telehealth Allied Health Assistant Survey}

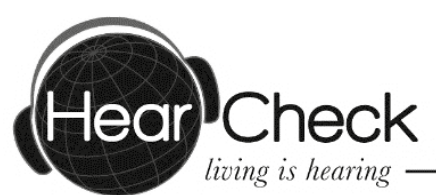

How satisfied were you with:

Excellent (4) Good (3) Poor (2) Fair (1) Not applicable (0)

The audiologist's ability to communicate with the client

The client's ability to communicate with the audiologist

The voice quality of the equipment

The visual quality of the equipment

The adequacy of telehealth as a method of service delivery in

audiology

Your personal comfort in using the Teleaudiology system

Your level of comfort and confidence in your abilities to assist

the delivery of services of the same quality as traditional face-

to-face appointments

The length of time spent with the client

The client's satisfaction and enjoyment of the service*

How well the staff answered your questions about the equipment

Additional Comments:

\section{Appendix D: Hear Check Telehealth Audiologist Survey}

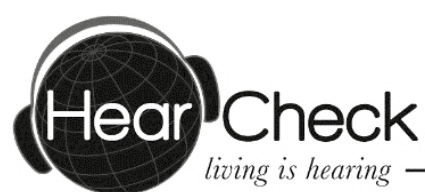

Hear Check Telehealth Audiologist Survey

\begin{tabular}{|c|c|c|c|c|c|}
\hline How satisfied were you with: & Excellent (4) & Good (3) & Poor (2) & Fair (1) & Not applicable (0) \\
\hline \multicolumn{6}{|l|}{ Your ability to communicate with the client } \\
\hline \multicolumn{6}{|l|}{ The voice quality of the equipment } \\
\hline \multicolumn{6}{|l|}{ The visual quality of the equipment } \\
\hline \multicolumn{6}{|l|}{$\begin{array}{l}\text { The adequacy of telehealth as a method of service delivery in } \\
\text { audiology }\end{array}$} \\
\hline \multicolumn{6}{|l|}{$\begin{array}{l}\text { Your level of comfort and confidence in your abilities to deliver } \\
\text { services of the same quality as traditional face-to-face appointments }\end{array}$} \\
\hline \multicolumn{6}{|l|}{ The length of time spent with the client } \\
\hline \multicolumn{6}{|l|}{ Your personal comfort in using the teleaudiology system } \\
\hline \multicolumn{6}{|l|}{ The client's satisfaction and enjoyment of the service* } \\
\hline How well the staff answered your questions about the equipment & & & & & \\
\hline
\end{tabular}

How did the delivery of audiological services via telehealth practices affect the following?

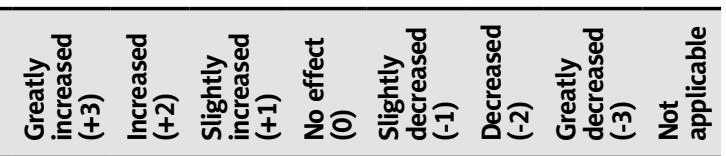

The quality of care in audiology

The quality of the interaction between the patient and the practitioner

The quality of the relationship between practitioners and new clients

The ability to discuss potentially private or embarrassing topics with clients

The ability to quickly meet with clients for urgent appointments

The need for technological troubleshooting 


\section{Appendix E: Interview Topic Guide}

We've asked you here today to talk about your experience with the Hear Check team and the online audiology appointment. We're hoping to gain an in-depth perspective on what you think worked, what didn't work and what can be improved. Before we get started, do you have any questions?

ICEBREAKER:
What has been your experience with Audiology?
Have you used video-conferencing before? How did you
find the experience with teleaudiology compared to any
other online video-conferencing experiences?
So, tell me how you found the whole experience, having
your hearing appointment online?
You've told me about the overall experience having
your hearing appointment conducted online. Next we're
going to walk through each of the different steps to
see what you think worked, what didn't work and what
improvements can occur.

Firstly, tell me about how you found out about Hear Check and what was your experience with making an appointment?

I now want to move onto the appointment itself, starting from when you walked into the There4U premises, all the way through to the end of the appointment. Tell me about that experience.

- Have you had a test before?

- How long ago?

- How did you find the interaction face to face?

- Have you used Skype before? How did the experience compare to that?

- Have you had any other medical appointments online?

- What about any work related experiences?

- What worked?

- What didn't work?

- Any improvements?

- Can you think of anything that might have made this process easier for you?

- Anything you weren't sure of?

- Did you ask any questions?

- How satisfying were the answers?

- Tell me about the interactions with the audiologist

- Tell me about the interactions with the allied health assistant

- What were you first impressions of the clinic room

\begin{tabular}{|c|c|}
\hline $\begin{array}{l}\text { How was the picture and sound quality during the } \\
\text { appointment? }\end{array}$ & $\begin{array}{l}\text { - Different to any prior experiences? } \\
\text { - Was the picture clear? } \\
\text { - Could you hear the Audiologist? }\end{array}$ \\
\hline Tell me what happened at the end of the appointment. & $\begin{array}{l}\text { - Did you find the process easy? } \\
\text { - Did you find the process too hard? } \\
\text { - What changes would you make? } \\
\text { - How could we have made it easier for you? }\end{array}$ \\
\hline \multicolumn{2}{|l|}{$\begin{array}{l}\text { Given that you're quite experienced with hearing } \\
\text { appointments, overall if the appointment was held face } \\
\text { to face instead, what do you think would have changed? }\end{array}$} \\
\hline OR & $\begin{array}{l}\text { - Was the service how you expected? } \\
\text { - What were you expecting? }\end{array}$ \\
\hline \multicolumn{2}{|l|}{$\begin{array}{l}\text { Given that you've never had a hearing test before, what } \\
\text { do you think would be different if the appointment was } \\
\text { held face to face? }\end{array}$} \\
\hline $\begin{array}{l}\text { Well that brings me to the end of my questions. Is there } \\
\text { anything else you would like to comment on? }\end{array}$ & \\
\hline
\end{tabular}

How could we have explained the appointment better for you?

experiences?

Did you find the process easy?

What changes would you make?

How could we have made it easier for you?

anything else you would like to comment on? 